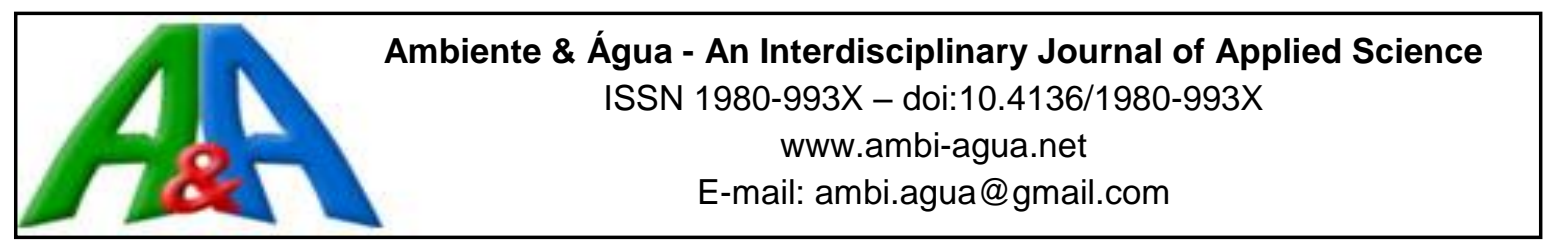

\title{
Impacts of land-use change on southeast Amazonia basin streamflow
}

\author{
ARTICLES doi:10.4136/ambi-agua.2303
}

Received: 22 Jul. 2018; Accepted: 24 Jan. 2019

\author{
Vinicius Marques Louzada*iD; Celso Bandeira de Melo Ribeiro \\ Universidade Federal de Juiz de Fora (UFJF), Juiz de Fora, MG, Brasil \\ Faculdade de Engenharia. Departamento de Engenharia Sanitária e Ambiental (ESA). \\ E-mail: vinicius.marques@engenharia.ufjf.br, celso.bandeira@ufjf.edu.br \\ *Corresponding author
}

\begin{abstract}
The Amazon region is the subject of growing interest in the international scientific community due to the environmental services provided by its dense forests in climate regulation and freshwater. Despite many efforts from environmental management agencies and research centers, this region can still be considered poorly monitored, especially given its large regional and global importance. Rainfall-runoff models are presented as a good alternative to the estimated flow rates in inaccessible or difficult to watch places. This study simulated stream flows for a representative part of the Amazon basin using the Soil and Water Assessment Tool (SWAT) redistributed hydrological model, adopting as reference the streamflow observed in Altamira gauge station. The authors emphasize that a database was specially prepared with physical parameters such as land use, topography and soil types, and weather data encompassing the years from 1985 to 2012, at a daily time step. The chosen approach allowed carrying out hydrologic simulations that were consistent with the flow values observed at the Altamira gauge station, providing better understanding of hydraulic-hydrological processes in the Xingu subbasin and information for planning and decision-making on the management of water resources in this important river basin.
\end{abstract}

Keywords: Amazon basin, hydrologic modeling, land use change.

\section{Impacto na mudança de uso do solo na vazão de uma bacia do sudeste da Amazônia}

\section{RESUMO}

A Região Amazônica vem despertando interesse crescente da comunidade científica internacional devido às amplas possibilidades ambientais que suas densas florestas têm a oferecer no que diz respeito à regulação climática e recursos hídricos. Apesar dos muitos esforços de agências reguladoras de meio ambiente e centros de pesquisa, esta região ainda pode ser considerada pouco monitorada, especialmente dada sua grande importância regional e global. Modelos de vazão são apresentados como uma boa alternativa para taxas de fluxos estimadas em lugares inacessíveis ou de difícil monitoração. O objetivo deste trabalho é simular vazões para uma porção significativa da Bacia Amazônica usando o modelo hidrológico semidistribuído SWAT (Soil and Water Assessment Tool), adotando como referência as vazões 
observadas na estação de monitoramento de Altamira. Ressaltamos que um banco de dados foi especialmente preparado com parâmetros físicos, como uso do solo, topografia e tipos de solo, e informações do clima compreendidas entre os anos de 1985 e 2012, numa escala de tempo diária. A abordagem metodológica permitiu que fossem realizadas simulações hidrológicas muito condizentes com os valores de fluxos observados na estação de monitoramento de Altamira, permitindo um melhor entendimento dos processos hidráulico-hidrológicos na subbacia do Xingu e fornecendo informação para planejamento e tomada de decisões no que concerne ao gerenciamento de recursos hídricos nesta importante bacia.

Palavras-chave: bacia Amazônica, modelagem hidrológica, mudança de uso do solo.

\section{INTRODUCTION}

The Amazon is one of the most complex ecosystems in the world; it is a place where it is possible to find researchers from all over the Earth trying to find new species or new medicine from plants (Gutbelert, 2002). Non-governmental and governmental organizations from all over the world also pursue the preservation of animals, plants and water resources (Goodwin, 2014).

Although it is known that natural resources must be preserved, the Amazon is facing issues with deforestation, especially for wood, commerce and plantations (Ferreira et al., 2005). According to Brazil's Ministry of the Environment, deforestation has decreased since 2004. However, the region still loses about $6000 \mathrm{~km}^{2}$ of natural forest every year. Another significant issue is the construction of the Belo Monte hydroelectric power plant, which is going to generate 11.233 MW of electricity and cause the inundation of $668 \mathrm{~km}^{2}$ (Berman, 2012).

Analyzing all that has been said, it was possible to conclude that studies should be done on that area to guarantee a sustainable exploitation of all natural resources. One type of study that is increasing worldwide is the use of mathematical models.

To plan the use of a basin and predict how this basin will respond to changes in soil use, deforestation and occupation, a mathematical model is used that simulates reality and provides an important tool to make the decisions. With a long data series, it is possible to estimate the impact of an action on a basin (Lenhart et al., 2002). Models are mathematical equations that intend to describe and simulate what will occur in the basin, and there are different models that can be used for a variety of purposes, according to the author's goal (Souza, 2015).

The model being used in this article is the Soil and Water Assessment Tool (SWAT) model. The SWAT model was developed by USDA Agricultural Research Service (USDA-ARS) and Texas A\&M AgriLife Research (Arnold et al., 1998). This model has recently been used in different hydrological studies in Brazil (Bressiani et al., 2015; Pereira et al., 2016). This research simulates different scenarios and how the streamflow responds to changes in land use.

\section{MATERIALS AND METHODS}

\subsection{Study Area}

The hydrological modeling was made in the Xingu River's subbasin (Figure 1), in the Amazon, between the coordinates UTM $8330743.862 \mathrm{~m}$ and $9851708.200 \mathrm{~m} ; 1319966.175 \mathrm{~m}$ and $1915083.081 \mathrm{~m}$. The basin has an approximate area of $509000 \mathrm{~km}^{2}$ that is distributed along the states of Mato Grosso (MT) and Pará (PA).

According to Koppen's classification model, the basin has two climates; the north part is classified as Am - Tropical Monsoon, with most of the rain occurring during the 7 to 9 hottest months. The rest of the basin the classification is Aw - Tropical Wet and Dry, where the precipitation occurs during the summer season and has a dry winter (Sampaio et al., 2011).

Rev. Ambient. Água vol. 14 n. 2, e2303 - Taubaté 2019 


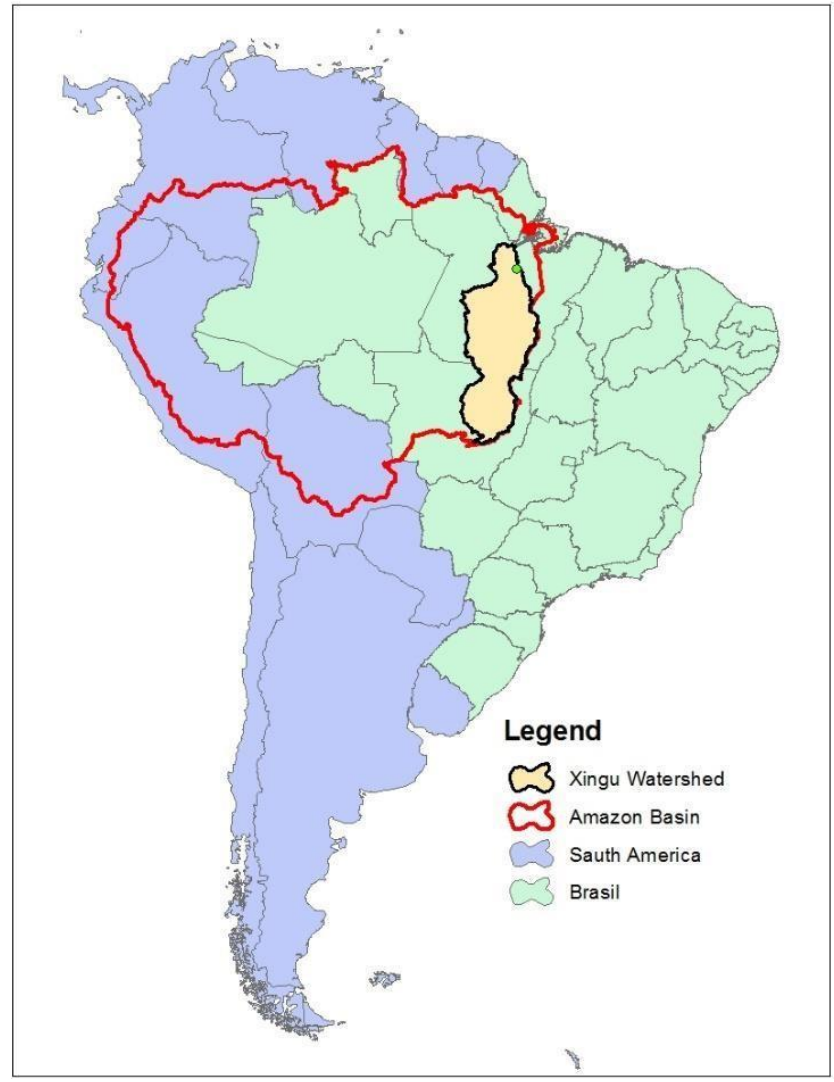

Figure 1. Xingú sub-basin, located in Amazon basin.

\subsection{Meteorological Data}

The meteorological data (relative humidity, solar radiation, wind speed and temperature) were obtained from 40 weather stations from INMET - National Meteorology Institute. Using this data, it was possible to calculate the necessary statistics for the model to run the simulation. It is noteworthy that rainfall data from 204 ANA - National Water Agency rainfall stations were used too.

\subsection{Types of Soil, Land Use Map, and Types of Soil and Land Use Map}

The main types of soils found in the Amazon basin are: Acrisol (38.47\%), Ferrasol (37.64\%) and Leptosol (11.78\%). The soil map (Figure 2a), with $5 \mathrm{~km}$ resolution was obtained in the ISRIC global database. The soil characteristics were obtained from the Pedo-Transfer Function (Saxton and Rawls, 2006). The land-use map (Figure 2b) was obtained from the MODIS sensor with a $1 \mathrm{~km}$ resolution (Friedl et al., 2010). The digital elevation models (Figure $3 a$ ) and slope maps (Figure 3b) were obtained from the TOPODATA global database (Hydrosheds), with a $1 \mathrm{~km}$ resolution.

The model was previously prepared in ArcGis with the following data: soil use, soils type, climatological data and the digital elevation model (DEM). The database comprehends the years between 1985 and 2012 .

The model was used to simulate streamflow in the basin cited above, during a period of 28 years, between 1985 and 2012, of which the first two years were used to warm-up the model.

The simulation results were imported to the Soil \& Water Assessment Tool - Calibration and Uncertainty Procedures (SWAT-CUP), where it is possible to do a static analysis and compare the data simulated by the program with the observed data. It is also possible to verify which parameters are more sensible, which allowed the calibration and validation of the model, making it possible to predict the stream flow in a more accurate way. 
a)

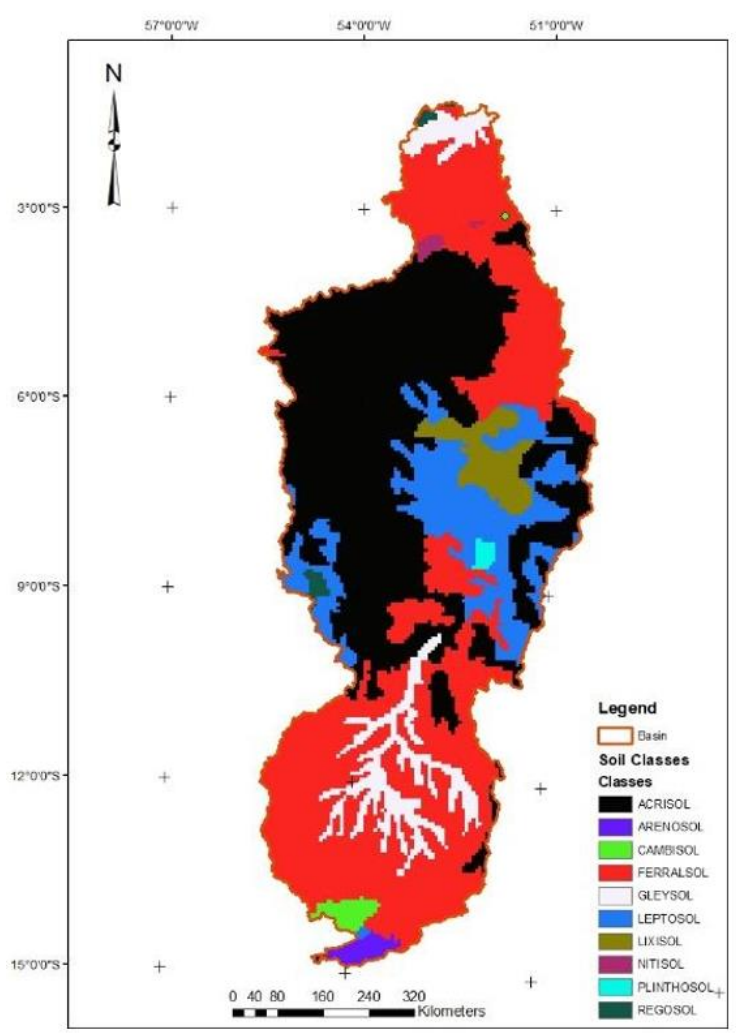

Figure 2. a) Types of soil; b) Land-use map.

a)

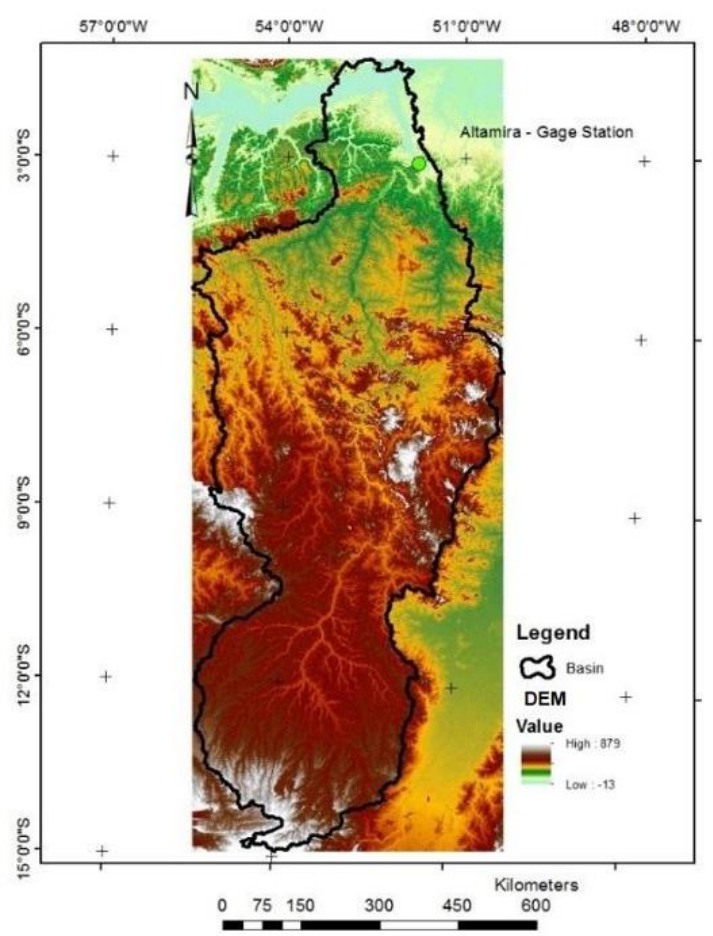

b)

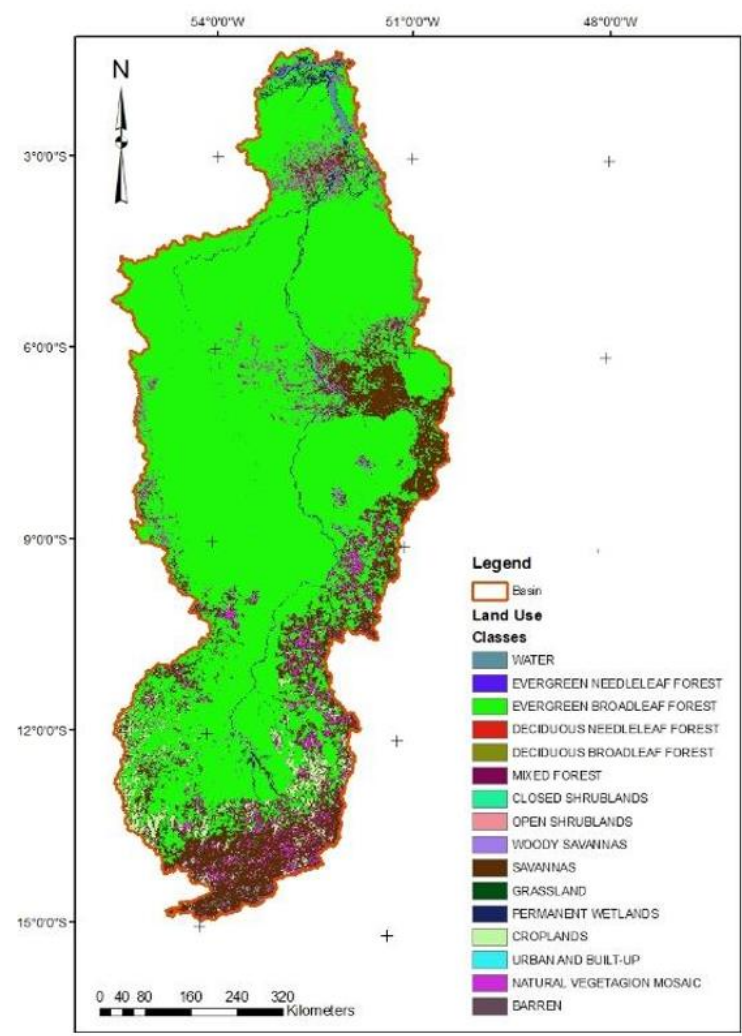

b)

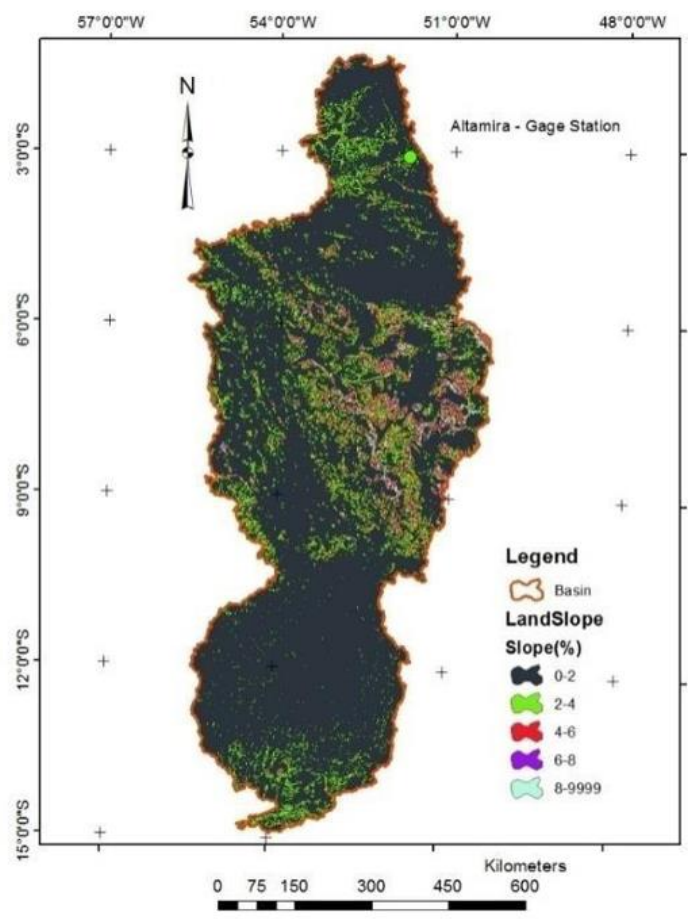

Figure 3. a) Digital Elevation Model; b) Slope map. 
For the calibration process, data from two monitoring points were used, belonging to the ANA - National Agency of Water. The first one at the beginning of the basin and the second at another point located in the course of the same river. The first monitoring point is named Boa Sorte (code 18460000). On this point, there is data available from January 1976 to February 2009. However, the model's database only starts on 1985; therefore, data from before that year was not taken into consideration.

After calibrating and validating the model, the values in all subbasins that contribute to the point where the first monitoring point is located were replaced. After changing the values, the model was run one more time. Next, the calibration and validation process for the second point, called Altamira (code 18850000), was initiated. Once again, the database available was larger than the model, so the authors only considered data from after 1985.

In the calibration and validation process for the second point, the values were only replaced on the subbasins between the first and the second points; the authors did not change any values on the subbasins that contribute for the first calibration point or the subbasins after the second point.

The second point was of interest because it is situated where the government of Brazil is building a hydroelectricity plant. Once the model is calibrated and validated, it will be possible to simulate and verify the impact of land use change in streamflow and power generation.

SWAT-CUP makes some statistical analyses and gives a few parameters to evaluate the model's efficiency. In this paper, the authors are going to use three parameters to check if the model is corresponding in a good way to reality.

\subsection{Statistical Evaluation Criteria}

Streamflow simulations were evaluated using different statistical criteria. According to Moriasi et al. (2007), the parameters that can be used are:

Coefficient of determination $\left(\mathrm{R}^{2}\right)$ : describe the proportion of the variance in measured data. $\mathrm{R}^{2}$ ranges from 0 to 1 and values greater than 0.5 are acceptable.

Nash-Sutcliffe efficiency (NSE): determine the relative magnitude of data variance compared to the measured data variance.

Percent bias (PBIAS): indicates the tendency of the simulated data to be larger or smaller than the observed values (Equations 1 and 2).

$$
\begin{gathered}
\text { NSE }=1-\frac{\sum_{i=1}^{n}(\text { Yobs }- \text { Ysim })^{2}}{\sum_{i=1}^{n}(\text { Yobs }- \text { Ymean })^{2}} \\
\text { PBIAS }=\frac{\sum_{i=1}^{n}(\text { Yobs }- \text { Ysim }) * 100}{\sum_{i=1}^{n}(\text { Yobs })}
\end{gathered}
$$

Model evaluations used in this study were based on performance ratings suggested by Moriasi et al. (2007) for a monthly time step, as shown in Tables 1 and 2.

Table 1. Reported performance ratings for PBIAS.

\begin{tabular}{lcccc}
\hline Model & Value & Performance rating & Modeling Phase & Reference \\
\hline SWAT & $<10 \%$ & Very Good & Calibration and Validation & Van Liew et al. $(2007)$ \\
SWAT & $<10 \%$ to $<15 \%$ & Good & Calibration and Validation & Van Liew et al. $(2007)$ \\
SWAT & $<15 \%$ to $<25 \%$ & Satisfactory & Calibration and Validation & Van Liew et al. (2007) \\
SWAT & $>25 \%$ & Unsatisfactory & Calibration and Validation & Van Liew et al. $(2007)$ \\
\hline
\end{tabular}

Adapted from Moriasi et al. (2007). 
Table 2. Reported performance ratings for NSE.

\begin{tabular}{|c|c|c|c|c|}
\hline Model & Value & Performance rating & Modeling Phase & Reference \\
\hline SWAT & $>0.65$ & Very Good & $\begin{array}{l}\text { Calibration and } \\
\text { Validation }\end{array}$ & Saleh et al. (2000) \\
\hline SWAT & 0.54 to 0.65 & Adequate & $\begin{array}{l}\text { Calibration and } \\
\text { Validation }\end{array}$ & Saleh et al. (2000) \\
\hline SWAT & $>0.50$ & Satisfactory & $\begin{array}{l}\text { Calibration and } \\
\text { Validation }\end{array}$ & $\begin{array}{l}\text { Santhi et al. (2001); adapted by } \\
\text { Bracmort } \text { et al. }(2006)\end{array}$ \\
\hline
\end{tabular}

Adapted from Moriasi et al. (2007).

\subsection{Land Use Change}

Images with the different types of land use were obtained from the MODIS Land Cover Product Type, (MCD12Q1). These products have annual basis and its historical series is available from 2001. These images were produced by supervised classification algorithms, with a spatial resolution of $500 \mathrm{~m}$, covering the soil surface of the planet (Friedl et al., 2010).

\section{RESULTS AND DISCUSSION}

\subsection{Calibration Process}

Lelis et al. (2012), Paim and Menezes (2009) and Andrade et al. (2013) present the most common parameter used to calibrate the SWAT model, especially for hydrology variables. Based on the parameter they presented, a few tests were made to check which one would be more sensitive for the specific model. After the simulations, the best parameters were determined and are shown in Table 3.

Table 3. Most sensitive parameters.

\begin{tabular}{|c|c|c|c|c|}
\hline Parameter & Description & Range of parameter & Best Value & Units \\
\hline CN2 & Surface runoff & 35 to 98 & 75.163 & - \\
\hline ESCO & Compensation of soil evaporation & 0 to 1 & 0.2958 & - \\
\hline ALPHA_BF & Base flow & 0 to 1 & 0.40416 & $1 /$ day \\
\hline RCHRG_DP & Deep aquifer percolation & 0 to 1 & 0.5458 & - \\
\hline SLSUBBSN & Average length of lateral ramp & 10 to 150 & 32.75 & $\mathrm{~m}$ \\
\hline EPCO & Compensation for plant grown & 0 to 1 & 0.85416 & - \\
\hline SURLAG & Surface runoff retardation coefficient & 0.05 to 24 & 20.3078 & - \\
\hline CH_W2 & Average width of main channel at top of bank & 0 to 1000 & 287.5 & $\mathrm{~m}$ \\
\hline CH_L2 & Length of main channel & -0.05 to 500 & 160.383 & $\mathrm{~km}$ \\
\hline CH_N2 & $\begin{array}{l}\text { Manning's roughness coefficient value for the } \\
\text { main channel }\end{array}$ & -0.01 to 0.3 & 0.200 & - \\
\hline
\end{tabular}

After determining which parameters should be changed, a simulation including all ten variables was made as to define the best value for each one. The statistical analysis is shown in Table 4. The data shown in the table is for the second point used.

Table 4. Calibration results.

\begin{tabular}{lcc}
\hline $\mathbf{R}^{\mathbf{2}}$ & NSE & PBIAS \\
\hline $\mathbf{0 . 6 3}$ & 0.59 & 17.3 \\
\hline
\end{tabular}

As stated by Rocha et al. (2012), the SWAT model is highly sensitive to the input data and $\mathrm{R}^{2}$ represents the correlation between observed and simulated data. As cited by the author and by Moriasi et al. (2007), values of $\mathrm{R}^{2}$ greater than 0.5 are usually acceptable. This shows a good correspondence between the values estimated by the model and the ones simulated by the program. 
For the NSE parameter, Moriasi et al. (2007) defines the range between 0.54 and 0.64 as adequate. This corroborates what Rocha et al. (2012) present values higher than 0.5 are not discarded, and other authors have used this efficiency. The value of 0.59 is classified as adequate for the specific model.

The last parameter used to evaluate the model was PBIAS; according to Moriasi et al. (2007), PBIAS can indicate poor model performance. The range of $15 \%$ to $25 \%$ is considered adequate by Van Liew et al. (2007). The value of $17.3 \%$ found after calibration was considered satisfactory.

All three parameters used to evaluate calibration process are sensitive to input data quality and indicate how well the model is representing the observed values in the basin. Analyzing the results shown in Tables 1 and 2, based on the literature, it was found that the model satisfactorily corresponds to the observed data.

\subsection{Land Use Change}

The land-use spatial-temporal analysis for the Xingu watershed was performed using MODIS images with $500 \mathrm{~m}$ spatial resolution along the 2001-2012 period, with sixteen different classes of land cover, as follows: evergreen needleleaf forest, evergreen broadleaf forest, deciduous needleleaf forest, deciduous broadleaf forest, savannas, grasslands, woody savannas, permanent wetlands, cropland/natural vegetation mosaic - CNVM, cropland, mixed forest, closed shrublands, open shrublands, urban and built-up and barren or sparsely vegetated.

The greatest identified coverage loss in Xingu watershed between 2001 and 2012 refers to the evergreen broadleaf forest class (Figure 4a), while the largest expansions occurred in the areas of savannas (Figure $4 \mathrm{~b}$ ) and croplands (Figure 4c), respectively.

a)

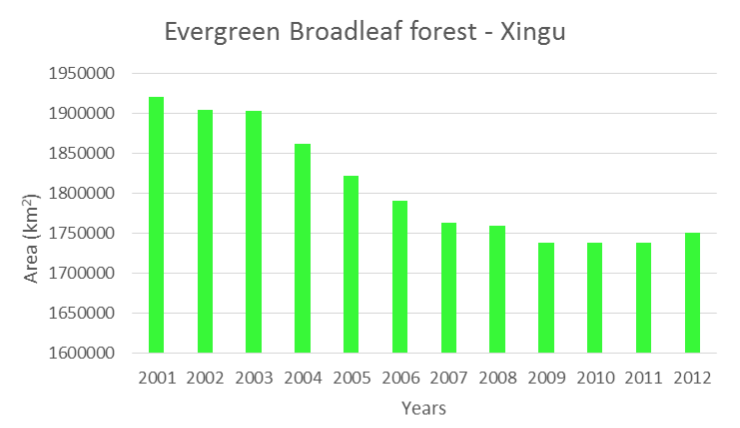

b)

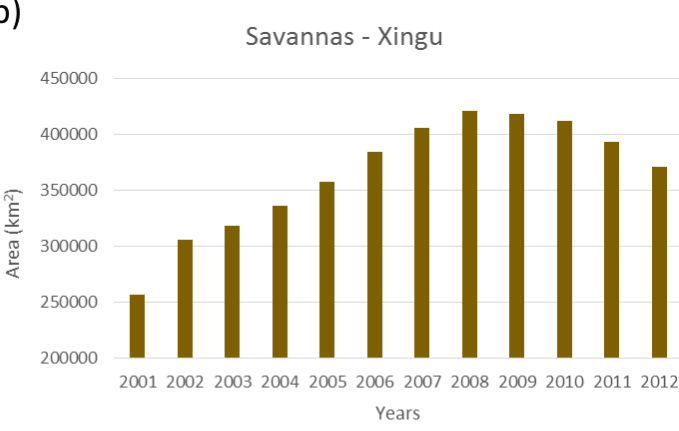

c)

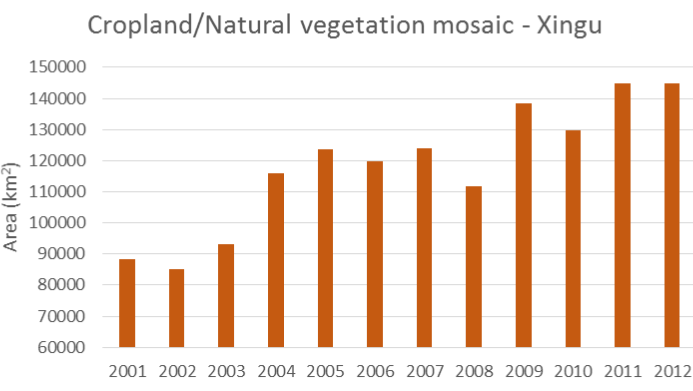

Years

Figure 4. Land use change in Xingu watershed: a) Evergreen Broadleaf Forest; b) Savannas, c) Cropland/Natural Vegetation Mosaic.

\subsection{SWAT Simulation}

After the calibration, two simulations were made using different land use maps: one for 2002, and another to 2012. The simulation dataset project present 307 watersheds with average area of around $1769.84 \mathrm{~km}^{2}$ (Figure 5). 

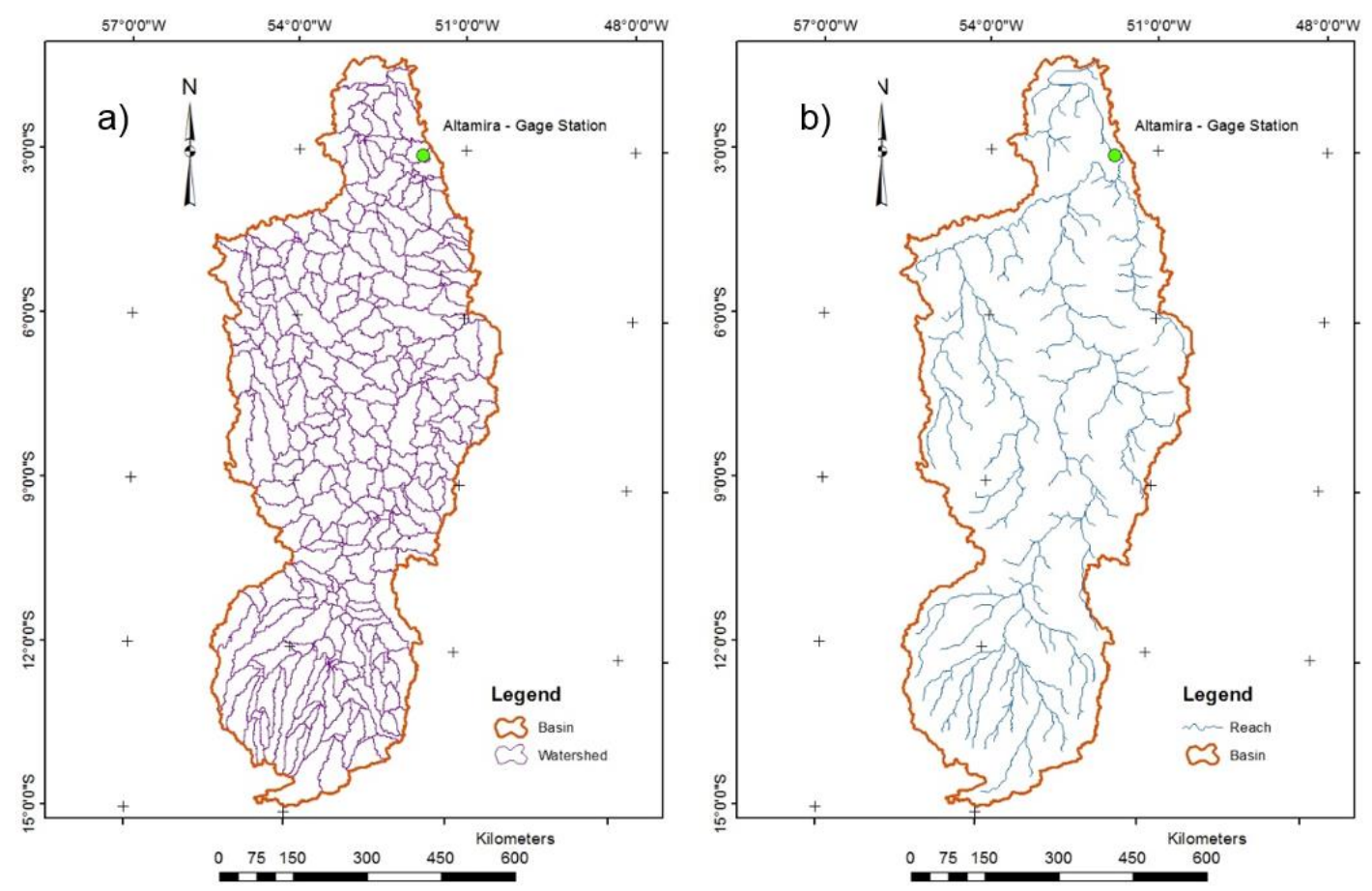

Figure 5. Discretization of representation watershed in SWAT model project for the Xingu: a) Watersheds; b) Stream.

Simulated and observed monthly flows at Altamira gauge station are presented for 01/1985 to 12/2012 in Figure 6, to visually evaluate the performance.

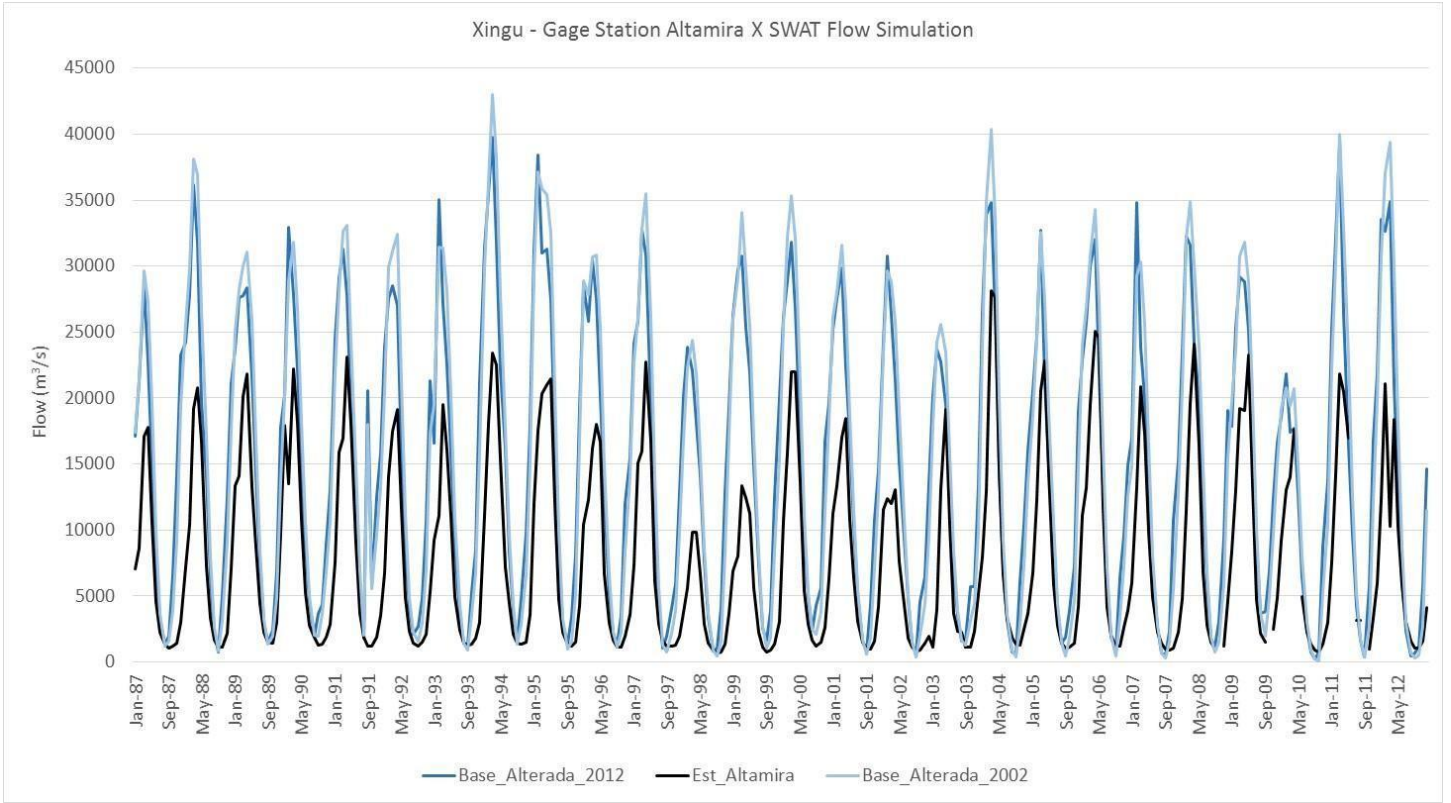

Figure 6. Observed and simulated monthly flows from 01/1985 to 12/2012.

Figure 6 shows that the simulated stream flows for 2002 and 2012 are higher than the observed data from Altamira station. It is also possible to observe on the graphic that simulated flow for 2002 is almost the same as for 2012, with a few higher peaks for the year of 2002. This fact goes against prediction, due to changes in land use, once the Evergreen Broadleaf forest had decreased as the Savanna had increased, less evapotranspiration and rainfall is expected, and an increase of water percolation, resulting in the decrease of streamflow in the Xingu River. 


\section{CONCLUSION}

The model has been calibrated for the subbasin of Xingu River, presenting satisfactory results for the years between 1997 and 1999. However, it is still possible to improve the calibration of the model, achieving a model that represents the reality in a more accurate way.

The streamflow results demonstrate that the land use change from 2002 to 2012 did not cause a significant difference at the Altamira gauge station. There little difference in power plant energy generation in Belo Monte during this period.

When properly calibrated and validated, the SWAT model is a very efficient tool to plan interventions and changes in basins. It saves time and can predict results for any modifications that may occur at the site.

\section{ACKNOWLEDGEMENTS}

We would like to acknowledge the financial support provided by $\mathrm{CNPq}$, Brazilian National Council for Scientific and Technological Development for conducting this research work.

\section{REFERENCES}

ANDRADE, M. A.; MELLO, C. R.; BESKOW, S. Simulação Hidrológica em uma bacia Hidrográfica Representativa de Latossolos na Região Alto Rio Grande, MG. Revista Brasileira de Engenharia Agrícola e Ambiental, v. 17, n. 1, p. 69-76, 2013.

ARNOLD, J. G.; SRINIVASAN, R.; MUTTIAH, R. S.; WILLIAMS, J. R. Large area hydrologic modeling and assessment-Part 1: Model Development. Journal of the American Water Resources Association, v. 34, n. 1, p. 73-89, 1998. https://doi.org/10.1111/j.1752-1688.1998.tb05961.x

BERMANN, C. O projeto da Usina Hidrelétrica Belo Monte: a autocracia energética como

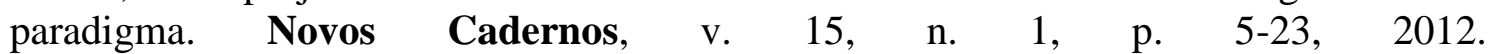
http://dx.doi.org/10.5801/ncn.v15i1.895

BRESSIANI, D. A.; GASSMAN, P. W.; FERNANDES, J. G.; GARBOSSA L. H. P.; SRINIVASAN, R.; BONUMÁ, N. B.; MENDIONDO, E. M. Review of Soil and Water Assessment Tool (SWAT) applications in Brazil: Challenges and prospects. International Journal of Agricultural and Biological Engineering, v. 8, n. 3, p. 9-35, 2015. http://dx.doi.org/10.3965/j.ijabe.20150803.1765

FERREIRA, L. V.; VENTICINQUE, E.; ALMEIDA, S. O desmatamento na Amazônia e a importância das áreas protegidas. Estudos Avançados, v. 19, n. 53, 2005. http://dx.doi.org/10.1590/S0103-40142005000100010

FRIEDL, M. A.; SULLA-MENASHE, D.; TAN, B.; SCHNEIDER, A.; RAMANKUTTY, N.; SIBLEY, A.; HUANG, X. MODIS Collection 5 global land cover: Algorithm refinements and characterization of new datasets. Remote Sensing of Environment, v. 114, n. 1, p. 168-182, 2010. https://doi.org/10.1016/j.rse.2009.08.016

GOODWIN, S. Forest Solutions. Vancouver: Greenpeace, 2014.

GUTBERLET, J. Zoneamento da Amazônia: uma visão crítica. Estudos Avançados, v. 16, n. 46, 2002. http://dx.doi.org/10.1590/S0103-40142002000300013

LELIS, T.A.; CALIJURI, M. L.; SANTIAGO, A. F.; LIMA, D. C.; ROCHA, E. O. Análise de Sensibilidade e Calibração do Modelo SWAT Aplicado em Bacia Hidrográfica da Região Sudeste do Brasil. Revista Brasileira de Ciência do Solo, v. 36, p. 623-634, 2012. 
LENHART, T.; ECKHARDT, K.; FOHRER, N.; FREDE, G. Comparison of two different approaches of sensitivity analysis. Physics and Chemistry of the Earth, v. 27, p. 645654, 2002. https://doi.org/10.1016/S1474-7065(02)00049-9

MORIASI, D. N.; ARNOLD, J. G.; VAN LIEW, M. W.; BINGNER, R. L.; HARMEL, R. D.; VEITH, T. L. Model Evaluation Guidelines for Systematic Quantification of Accuracy in Watershed Simulation. American Society of Agricultural and Biological Engineers, v. 50, n. 3, p. 885-900, 2007. http://dx.doi.org/10.13031/2013.23153

PAIM, J. B.; MENEZES, J. T. Estimate of Sediment Budget of the Tijucas River Basin Applying SWAT Hydrologic Model. Revista Geográfica Acadêmica, v. 3, n. 2, 2009.

PEREIRA, D. R.; MARTINEZ, M. A.; PRUSKI, F. F.; SILVA, D. D. Hydrological simulation in a basin of typical tropical climate and soil using the SWAT model part I: Calibration and validation tests. Journal of Hydrology: Regional Studies, v. 7, p. 14-37, 2016. https://doi.org/10.1016/j.ejrh.2016.05.002

ROCHA, E. O.; CALIJURI, M. L.; SANTIAGO, A. F.; ASSIS, L. C.; ALVES, L. G. S. The Contribution of Conservation Practices in Reducing Runoff, Soil Loss, and Transport of Nutrients at the Watershed Level. Water Resourses Management, v. 26, n. 13, 2012. https://doi.org/10.1007/s11269-012-0106-1

SAMPAIO, M. S.; ALVES, M. C.; SANCHES, L. Uso de Sistema de Informação Geográfica para comparar a classificação climática de Koppen-Geiger e de Thornthwaite. In: SIMPÓSIO BRASILEIRO DE SENSORIAMENTO REMOTO, 15., 2011, Curitiba. Anais[...] São José dos Campos: INPE, 2011.

SAXTON K. E.; RAWLS, W. J. Soil Water Characteristic Estimates by Texture and Organic Matter for Hydrologic Solutions. Soil Science Society of Agronomy Journal, v. 70, n. 5, p. 1569-1578, 2006. http://dx.doi.org/10.2136/sssaj2005.0117

SOUZA, V. A. S. Monitoramento Hidrossedimentológico com Suporte do Modelo SWAT na Amazônia Ocidental - Bacia do Rio Machadinho/RO. 2015. Dissertaão (Mestrado em Engenharia Civil) - COPPE, UFRJ, 2015.

VAN LIEW, M. W.; VEITH, T. L.; BOSCH, D. D.; ARNOLD, J. G. Suitability of SWAT for the conservation effects assessment project: A comparison on USDA-ARS experimental watersheds. Journal of Hydrologic Engineering, v. 12, n. 2, p. 173-189, 2007. https://doi.org/10.1061/(ASCE)1084-0699(2007)12:2(173) 